quote but a few examples, we have the Danakil haha, air ; Seneca gahah, wind, and gaoh, air (cf. gas); Tibetan gak-pa, to be choked; Inca chanani, to kindle; Persian gand, stink; Urdu gandhak, sulphur; Japanese hana, nose, flower, the first; the Ancient Egyptian $\overline{c h} a$, to enter, and $\overline{c h}$ en, flowers; $K a$, the eidolon or familiar; Gipsy cannelo, stinking, and nok, nose; Melanesian gnoko and Eskimo kenowk, nose; Circassian $\overline{c h a s s a}$, to learn; Arabic chassat, sense of smell; Inca $\overline{c h}$ osni, smoke, and humpi, sweat; Chinook humm, stink (Ar. shamm, to smell ; Russian, shaman, sorcerer; etc.); Inca, chuncu, stink; Yao nunga, smell; Suahili and Zulu nuka, Congo nukana, and Chinyanja nunkisa, to smell; Russian nyuchat, to smell (cf. nauk, science).

The significance of the combination of the nasal and guttural sounds in connexion with smell may be seen by means of the following, somewhat rough, expedient. Taking roo words signifying nose from Asia, Europe, Africa, Australia, the South Sea Islands, and America, and analysing the sounds present, it was found that of the 235 consonants present, IO2 were $\mathrm{n}, \mathrm{ng}, \mathrm{h}, \mathrm{k}, \overline{\mathrm{ch}}$, and $\mathrm{q} ; 59$ were $s, z$, sh, $z h, j$, tch, $d$, and $t ; 35 \mathrm{r}$ and $1 ; 20 \mathrm{~b}, \mathrm{p}, \mathrm{f}, \mathrm{v}$; and $\mathrm{I} 9 \mathrm{~m}$. Of the 224 vowel sounds represented 63 were $u, w ; 53 a ; 47 \mathrm{i}, \mathrm{y} ; 36 \mathrm{o}$, ö; and $25 \mathrm{e}$, ä. While this method does not commend itself to philologists, it may serve to indicate a new way of building up an international language, based on the physiological reactions to stimuli, and in any case affording food for thought and discussion. It must be borne in mind that the few examples quoted above do not necessarily indicate their ontogeny. Perhaps what has been said about the nose may suggest even a connexion with the Ankh, and may not the anchor perhaps suggest a nasal symbolism ?

The Homestead, Clynder,

JohN H. KeNNETH. October I4.

\section{Could the Romans in Britain weld Iron?}

INCREASING attention has, within the last few years, been devoted to Roman remains in Britain, and a great deal of interest centres round such metallic remains as have survived from this period. Iron was always manufactured by the so-called " direct" process, that is, iron ore was reduced with charcoal direct to the metal without the intermediate formation of pig iron. The method was very wasteful, and in the further working of the metal so much oxidation took place that frequently the whole of the metal disappeared, the finished article consisting almost entirely of the hard ferrosoferric oxide, the remainder being slag or other impurity. This was the case with certain " iron " nails from the Roman villa at Folkestone which were forwarded to me by Mr. S. E. Winbolt.

As the Roman method of heat treatment was so crude and resulted in so much oxidation, I have often wondered if it was possible for them to weld their iron. Through the kindness of Mr. Walter G. Klein, I have been able to examine specimens of Roman iron from the excavations at Richborough, and an account of these was laid before the autumn meeting of the Iron and Steel Institute by Mr. W. E. Thorneycroft and myself. One piece of iron, when sawn through, showed that it consisted of a bundle of about 8 rods which had apparently been hammered together to make them unite. But metal did not touch metal, for each rod was separated by a thick layer of impurity, containing 45.47 per cent. of iron and 24.54 per cent. of insoluble material, mainly silica. The rods held together with surprising ten- acity, but a heavy blow cracked the cementing material, when they readily fell apart.

An iron ring was examined from the same source, and we thought that this might indicate whether or not the Romans could weld. At first we thought we had a clue. There was a distinct crack visible under quite low magnification at one part of the ring. But on further grinding this disappeared and no further evidence of a weld was obtained. The ring might therefore have been made by driving a hole through a plate, for its external diameter was only $4^{\circ} \mathrm{cm}$., the mean diameter of the metal being $0.75 \mathrm{~cm}$.

A week or two ago I received from Mr. Francis B. Andrews, secretary of the Birmingham Archæological Society, a piece of Roman iron pipe from Uriconium. It was a ring of metal, not unlike a serviette ring, $4.3 \mathrm{~cm}$. in diameter and $\mathrm{I} \cdot 5 \mathrm{~cm}$. deep. On grinding down it became evident that the ring had been made by bending over upon itself a piece of sheet iron and cementing or "soldering" the join with molten copper or copper alloy.

There has not yet been time to examine the specimen micrographically, or to determine the particular composition of the cupriferous " solder." A full description of these will, it is hoped, appear in due course.

Searching through the literature, I have been unable to find any reference to this kind of thing before, and it would be most interesting if any of the readers of NATURE could cite further examples.

One of the great difficulties of work of this kind lies in the fact that the antiquary naturally desires to preserve his "finds " and hesitates to allow objects of interest to be examined by any chemical or metallurgical process that may tend to destroy them. With this we all sympathise. Yet where specimens are not unique, but fairly common, it might be possible to hand some of these over to tried investigators in order that science might benefit by a further examination, even at the risk of spoiling for exhibition purposes these duplicated specimens.

My sincerest thanks are due to those gentlemen who have so generously placed at my disposal the material discussed in this note.

Municipal Technical School,

Suffolk Street, Birmingham, October 27.

\section{Weather Prediction from Observations of Gloudlets.}

I Do not think that the method described by Sir G. Archdall Reid in NATURE of November 7, p. 676 , is at all of universal application. It certainly cannot be applied to cirro-cumulus ; the cloudlets composing lenticular cirro-cumulus not only may wax at one end of the cloud and wane at the other, as mentioned by Sir G. Archdall Reid, but they always behave in this way; I do not think that any of the explanations he gives accounts for the phenomenon, but the point is not to account for it, but to decide whether the waxing or the waning of the cloudlets is to be taken account of in weather prediction. Again, a whole mass of cirro-cumulus cloudlets may form and disappear in a very short time ; is the appearance or the disappearance to be reckoned with? The lower clouds seem to me to tell even more against the method; on almost every fine summer morning we may watch cloudlets waxing, but it by no means follows that rain will result; probably in nine cases out of ten it will not. I should imagine that there must be nearly a hundred days every year when the method is disproved by the waxing of cloudlets which will develop not into rain clouds, but into the cumulus of a fine day.

Stoner Hill, Petersfield, November 9.

$$
\text { NO. } 2925 \text {, VOL, II } 6]
$$

